\title{
Optimized Solution for Increasing Electricity Access with Mini-Grid Technology in Nigeria
}

\author{
Chukwuma Leonard Azimoh ${ }^{1} \&$ Charles Mbohwa ${ }^{1}$ \\ ${ }^{1}$ Department of Quality and Operations Management, Faculty of Engineering and Built Environment, University \\ of Johannesburg, Johannesburg, South Africa \\ Correspondence: Chukwuma Leonard Azimoh, Department of Quality and Operations Management, Faculty of \\ Engineering and Built Environment, University of Johannesburg, Johannesburg, South Africa. E-mail: \\ lcazimoh@gmail.com
}

Received: November 7, 2018

Accepted: December 24, 2018 Online Published: January 31, 2019

doi:10.5539/jsd.v12n1p156

URL: https://doi.org/10.5539/jsd.v12n1p156

\begin{abstract}
Electricity challenge in Nigeria is such that only a dramatic increase in both generation and distribution capacity could leapfrog it out of the situation. Reports show that about $61 \%$ of the population have access to electricity, and those that do have are currently grappling with epileptic supply. The power network has installed capacity of about $12.5 \mathrm{GW}$ whereas the distribution network has capacity for about $6.8 \mathrm{GW}$, and often only about $4.5 \mathrm{GW}$ is available to the consumers. Shortfalls are often met with private generations using diesel generators, resulting in noise and environmental pollution with the attendant health consequences. Frightfully so, the challenge is further exacerbated by the burgeoning population. Nevertheless, the government have set an ambitious target for increasing electricity access in VISION 2030 national development plan. A major milestone of this policy is the audacious ambition to increase the existing grid capacity to $30 \mathrm{GW}$, with $30 \%$ of the mix coming from low carbon technology sources. This study explores the use of available renewable energy resources at eleven locations in different regions of the country for optimal generation of energy in contribution to the Nigerian energy matrix. The study was conducted using HOMER ${ }^{\mathrm{TM}}$ and Power BI models. Four energy sources were investigated comprising of solar, wind, hydro and diesel. Our findings show that most places in the southern and middle belt of the country support mini-grid systems but are more receptive to grid extension, while a majority of the locations in the north are more environmentally friendly to the implementation of mini-grids. In addition, solar technology contributes more than $80 \%$ to the energy mix in most places investigated in the south. Meanwhile, most northern locations despite having higher solar irradiation, wind technology contributed above $60 \%$ energy to the mix.
\end{abstract}

Keywords: low carbon technology, mini-grid, Nigeria, renewable energy resource optimization, renewable energy Investment potential, greenhouse gas emission, low electricity access

\section{Introduction}

Low electricity access has become a metaphor for poverty and underdevelopment in most developing countries. It has been argued that the consumption of electricity per capita has a direct correlation with development index; in fact, it has been used as a measure of the economic well-being of a people (Ferguson, Wilkinson, \& Hill, 2000). However, there are disparities in access to electricity between developed nations, and developing ones. Pereira et al. reported in their treatise reported that energy consumption per capita in Africa is $153 \mathrm{kWh} /$ year, India $94 \mathrm{kWh} /$ year, China $181 \mathrm{kWh} /$ year, USA $4390 \mathrm{kWh} /$ year, Canada $4737 \mathrm{kWh} /$ per year and Brazil $2400 \mathrm{kWh} /$ year (Pereira, Freitas, \& da Silva, 2010). It has also been stated that the relationship between energy and development are hinged on four basic necessities, namely, survival, basic quality of life, amenities and internal collaboration, and that for a necessary condition for education and conducive environment to exist, consumption of electricity must be higher than $1000 \mathrm{kWh} /$ year per capita, with anything lower than the benchmark, only the basic condition of survival is guaranteed (Yeagar, 2012). Nevertheless, recently updated data on country-by-country energy status from WEO 2017 shows that the rate of connections to electricity annually has gained momentum over the last five years, the assessment of the trend indicate that several countries are on track to meeting electricity for all target by 2030 (IEA, 2017). A combination of many factors, such as the continued expansion of grid connections, the declining cost of renewable energy systems, entrance of 
business savvy entrepreneurs with access to a robust finance streams using innovative business models has been attributed to the success (IEA, 2017).

Despite the widespread global progress, sub-Saharan Africa is an outlier with the trend, since increased connection lags population growth. It is projected that by 2030, 600 million out of the 674 million people without access to electricity will be domiciled in sub-Saharan Africa, mainly in rural areas (IEA, 2017).

In Nigeria, low electricity access has assumed the dimension of a crisis. A recent report indicates that about $61 \%$ of the population have access to electricity (IEA, 2017), ((IRENA, 2016)). The situation is made worse by the unreliable and problematic power network, often characterized with load shedding, illegal and inflated charges by officials and epileptic supply. Factors such as unavailability and irregularity in supply of gas, breakdowns, water shortages and grid constraints also affect reliability of power (Ley, Gaines, \& Ghatikar, 2014). Consequent upon this, users resort to captive generation of electricity; private generators using diesel fuel are common sights in urban and suburb communities, resulting in noise, environmental pollution (Note 1) and attendant health consequences. Furthermore, this situation has increased the cost of doing business and energy burden in manifold. At the domestic level, most of the people still depend on biomass for cooking, which often lead to foraging in farmlands and forests for firewood mostly by rural dwellers, contributing regrettably to deforestation. With a growing population of over 187 million (UN projection), out of which more than $39 \%$ do not have access to electricity portends danger for the future. This could be worse going by the standard definition of electricity access by IEA, who defines energy access as "a household having reliable and affordable access to both clean cooking facilities and electricity enough to supply a basic bundle of energy services initially, and then an increasing level of electricity over time to reach the regional average"(IEA, 2017).

Nigerian electricity network is predominantly fossil based, with gas power thermal plants and hydro plants representing about $86 \%$ and $14 \%$ of the total generation respectively, as of May 2015 the installed capacity was about $12.5 \mathrm{GW}$, but due to gas shortage the available capacity was about $6.8 \mathrm{GW}$, while the distribution network can only evacuate about $4.5 \mathrm{GW}$ through its corridor as a result of network constraints (Roche et al., 2017a). In addition to this shortcoming, the grid networks, which are largely underutilized and poorly maintained were installed more than thirty years ago. Traditionally, the power utility network has been owned, controlled and operated by the government. For this reason, political and economic considerations affect grid extension programs, priorities are placed on economic and political interests, therefore, most often, the Federal capital territory, state capitals, local government headquarters are served first, leaving a swathe of remote rural settlements out of the grid. Ironically, these deprived regions are locations with abundant renewable energy based resources sufficient to meet the energy needs of the bourgeoning population. Despite the abundant resources, the penetration of renewable energy systems is disproportionately low. Nonetheless, the government is making efforts towards increasing electricity access in the country through the establishment of national energy development plan (NEDP) program, a precursor to vision 20:2020 (Note 2) and 30:2030 programs (Note 3), which are consistent with the objectives of United Nations Framework Convention on Climate Change (UNFCCC), these among others, support the implementation of policies and investments along green growth pathways (Cervigni, Rogers, \& Henrion, 2013).

Hitherto, the penetration of mini-grid technology in the transmission network of sub-Saharan Africa has remained abysmally low despite the ubiquitous renewable energy resources in this region due to challenges. A major constraint has been the huge capital requirement for generation of renewable energy-based electricity. The rule of thumb used in the industry holds it that generation accounts for between $60 \%$ and two-thirds of the total electricity cost, with the other two, together with marketing costs, adding up to between one-third and $40 \%$ (IRENA, 2016). According to a previous report, initially, diesel generators were used to meet the energy needs of the off-grid, but the one-off-pay acquisition capital requirement and running costs is a major drawback (Ichord, Jr., 2016), (Pueyo, Bawakyillenuo, \& Osiolo, 2016),(C.L. Azimoh, Klintenberg, Mbohwa, \& Wallin, 2017).

In solving the issue of low electricity access in most developing countries, Mini-grid has been recommended as a veritable means of augmenting the electricity shortfall, given the limitations of the utility grids (Okpukpara \& Ibiyemi, 2016). However, mini-grid based electricity market faces several challenges in several developing countries, including risky business environment due to unknown consumer characteristics and unfamiliar business terrain, weak institutional arrangements arising from non-supportive regulatory policies, limited access to low cost long term finance and inadequacies in local skills and capacities (Bhattacharyya \& Palit, 2016). Another report observed that, while there are no fundamental technical challenges that militate universal energy access, lack of strong institutions, effective business models and policy frameworks affects outcomes (Bhattacharyya \& Palit, 2016), (Oji \& Weber, 2017). In the same breath, energy crisis has been attributed to weak governance, limited organizational skills and unfavorable regulatory policies (Longe, Rao, Omowole, 
Oluwalami, \& Oni, 2017). An analysis of mini-grid viability in South Africa indicates that dispersed homesteads, remoteness of small villages, high costs of electricity production, transmission, and distribution, including losses, limited funding support and low return-on-investment are causative factors for non-implementation of off-grid projects in some developing countries (DME, 2008).

As much as this is the case, an assessment of energy resources in Africa shows that the sub-Saharan African regions have very high potential for grid-connected wind, hydro, geothermal, biomass and solar power development (IRENA, 2016). In no distant past, a major inhibition for implementation of mini-grid electrification program has been the issue high economic cost, lack of policy and political will to embark on projects of this nature. However, the advancement in technology has made it possible for provision of electricity to the un-electrified segment of the off-grid population using renewable energy systems in the developing world. Therefore, it is expected that Nigeria and indeed other developing countries should leverage on this to increase energy access in their respective regions.

This paper presents options for making informed economic decisions on the choice of low carbon technology in specific locations of Nigeria. To achieve this objective, the three key questions underscores the study conducted in this manuscript are as stated below.

- How can the low energy excess situation in Nigeria improve?

- What should be done to bring about geographical balance in generation and distribution network?

- What option is the best solution for increasing electricity access in Nigeria?

This study projects the development of low carbon technology systems as an option that could spur growth in socio-economic development of developing countries, through reduced carbon emission, and resilient energy systems. In addition, it provides a guide to enable delineation and harmonization of geographical locations appropriate for installation of a given technology, it could also help national electrification planning based on efficient and optimal use of available resources. Furthermore, this paper will provide material for an extended opinion on investment choices to investors interested in Nigerian electricity market.

\subsection{The Nigerian Power Sector Reform}

The challenges in the power sector were the driving forces behind the establishment of Nigerian Power Sector Reform Act (NPSRA) that led to the vertical and horizontal unbundling of Nigeria electricity industry. The outfall of this was the transformation of national utility network, National Electricity Power Authority (NEPA) to a holding company known as the Power Holding Company of Nigeria (PHCN). The reform was carried out in such a way that it ensures that the government retains some level of responsibility, it divested $51 \%$ of her equity shares in power generation, and vertically unbundled it to 6 companies, contracting transmission company of Nigeria (TCN) to Manitoba Hydro International Canada under 5-year management agreement, the distribution company were horizontally unbundled into 11 regional distribution companies (Ptfp \& Pacp, 2010). The reforms reduced the function of the government and limits it to the level of an equity investor, as well as providing legal and regulatory functions to enable conducive private sector participation. Consequent upon this, the following action plans were also carried out, the Presidential Action Committee on Power (PACP) and the Presidential Task Force on Power (PTFP) were established, the Roadmap for Power Sector Reform was released, and the Bulk power trader was established. Despite these efforts, paradoxically, the effect of these reforms is yet to be felt downstream.

\subsection{History of Off-Grid Electrification and Mini-Grids in Nigeria}

Mini-grid could be defined as an electricity network supplying a given community, it could be grid connected or island operated. IRENA defined Mini-grid as an integrated energy infrastructure with energy resources and loads. Its functions are energy generation, storage, energy conversion, control, measure and manage (CMM) (IRENA, 2016). The mini-grid debut has had low penetration in SSA region principally due to high generation costs. However, recent report indicates a decline in cost, with projections for further decrease, according to the analysis, the levelized cost of an autonomous mini-grid using only renewable energy is expected to drop to between "USD 0.30 per kilowatt-hour ( $\mathrm{kWh}$ ) to USD $0.57 / \mathrm{kWh}$ by 2025 , and to a range of USD $0.19 / \mathrm{kWh}$ to USD $0.35 / \mathrm{kWh}$ by 2035. Current costs are between USD 0.47/kWh and USD 0.92/kWh" ((IRENA, 2016)). Giving the intermittent nature of the utility grid, proliferation of low cost and substandard diesel generators resulting in air, noise and environmental pollution, recent decline in the price of renewable energy systems, the abundant solar resources and preponderances of other renewable energy resources, and millions of off-grid rural population segment yet to be electrified, mini-grid option beckons a viable pathway towards increasing electricity access in developing countries. In SSA, grid connected mini-grids are not common, the existing mini-grids are mostly localized with 
no interaction with the utility grid. It has been argued that one of the best options of increasing energy access in SSA region is a policy shift towards the inclusion of private energy generators in the electricity network (Azimoh, Dzobo, \& Mbohwa, 2018). It is the believe of the authors that a wide spread integration of captive power generators in the energy stream could attract more private power producers through prosumer concept in the energy market.

Even though the country has had a long history of off-grid electrification program, mini-grid development remains at its infancy and a lot needs to be done to increase the electricity access, which stands pejoratively low at $61 \%$. The first local energy supply initiative was in 1929, under the name Nigerian Electricity Supply Company (NESCO). With about $26 \mathrm{MW}$ from hydro based mini-grid system. NESCO supply 24/7 electricity to rural communities in about 7 local government areas of Plateau state in North Central part of Nigeria. Today, NESCO has been granted a 25-year license to supply energy to many rural communities in the middle belt states of Nigeria due to their outstanding performances over the years (Allon, 2018). Other success stories of implemented off-grid electrification projects in Nigeria and the adopted operating models are as depicted in Table 1 .

Table 1. Successful off-grid projects in Nigeria

\begin{tabular}{|c|c|c|c|}
\hline Company & Location & Renewable Resource and Capacity & Operating model and Success factors \\
\hline $\begin{array}{l}\text { Green Village } \\
\text { Electricity } \\
\text { (GVE) }\end{array}$ & $\begin{array}{l}\text { Katcha (Niger state), Anambra West (Anambra state), Kaltungo, } \\
\text { Balanga, Biliri (Gombe state), Demshin, Angwan Rina (Plateau } \\
\text { state), Onna (Akwa lbom), Etche (River state) }\end{array}$ & $\begin{array}{l}\text { Solar PV, capacity } 500 \mathrm{~kW} \text { solar mini- } \\
\text { grids serving over } 5,200 \text { households }\end{array}$ & $\begin{array}{l}\text { Sales through network of vendors, } \\
\text { dicount tariff for SMEs. Tax break, } \\
\text { community engagement, off-take } \\
\text { capital from donor agencies }\end{array}$ \\
\hline \begin{tabular}{|c|}
$\begin{array}{c}\text { Nigeria Electricity } \\
\text { Supply Company } \\
\text { (NESCO) }\end{array}$ \\
\end{tabular} & $\begin{array}{l}\text { Kura,Tin mines in the Benue-Plateau area of Nigeria, } 7 \\
\text { local government areas (Plateau state) }\end{array}$ & $\begin{array}{l}\text { Hydro, with installed capacity of } 26 \mathrm{MW} \\
\text { of hydro plants, serving }\end{array}$ & $\begin{array}{l}\text { Long lasting relationship with } \\
\text { communities and other } \\
\text { stakeholders, skilled professionals, } \\
\text { robust maintenance culture }\end{array}$ \\
\hline $\begin{array}{l}\text { Presco PIc } \\
\text { (PRESCO) }\end{array}$ & $\begin{array}{l}\text { Palm oil milling and refining factory staff housing estate (Edo } \\
\text { State) }\end{array}$ & $\begin{array}{l}\text { Biomass and Biogas with installed } \\
\text { capacity of } 8 \mathrm{MW}\end{array}$ & $\begin{array}{l}\text { Locally available feedstock, cost } \\
\text { reduction through recycling }\end{array}$ \\
\hline $\begin{array}{l}\text { Bonny Utility } \\
\text { Company (BUC) }\end{array}$ & Bonny Kingdom (Rivers State) & $\begin{array}{l}\text { Gas, gas turbine generated electricity } \\
\text { supplying over } 10,000 \text { households }\end{array}$ & $\begin{array}{l}\text { Involvement of joint industry } \\
\text { company (JIC)- Shell, NLNG,Bonny } \\
\text { Kingdom, Ministry of power reduced } \\
\text { cost to } 20 \% \text { off utility rate }\end{array}$ \\
\hline $\begin{array}{l}\text { Alausa Power } \\
\text { Limited (APL) }\end{array}$ & $\begin{array}{l}\text { Government parastatals, } 120 \text { households in three government } \\
\text { staff quarters, street lighting (Ikeja-Lagos state) }\end{array}$ & $\begin{array}{l}\text { Gas, serving } 4,000 \text { government staff, in } 40 \\
\text { parastatals, } 120 \text { households staff quarters, } \\
\text { and over } 70 \mathrm{~km} \text { of street lighting }\end{array}$ & $\begin{array}{l}\text { A 10-year take-or-pay Power } \\
\text { s, Purchase Agreement (PPA), prepaid } \\
\text { metering helps revenue collection }\end{array}$ \\
\hline $\begin{array}{l}\text { Lumos Nigeria- } \\
\text { MTN Nigeria }\end{array}$ & $\begin{array}{l}\text { Leveraging on the geographical spread of MTN, Lumos serves } \\
\text { over } 75,000 \text { Households across Nigeria }\end{array}$ & $\begin{array}{l}\text { Solar Home Systems (SHS), with } \\
\text { installed capacity of over } 6 \text { MW serving } \\
\text { about } 75,000 \text { households nation wide }\end{array}$ & $\begin{array}{l}\text { Retrofiting of sales in MTN } \\
\text { established market network nation } \\
\text { wide, pay as you go tarrif, } 80 \mathrm{w} \mathrm{PV}\end{array}$ \\
\hline $\begin{array}{l}\text { Energizing } \\
\text { Economies } \\
\text { Initiative (EEI): }\end{array}$ & $\begin{array}{l}\text { Sabon Gari Market (Kano State), Ariaria Market (Abia State), } \\
\text { and Sura Market (Lagos State) and developing } 13 \text { new projects } \\
\text { across the country }\end{array}$ & $\begin{array}{l}\text { Micro, targeting Small and Medium } \\
\text { Enterprises (MSME), serving over } \\
100,000 \text { shops and other business } \\
\text { clusters }\end{array}$ & $\begin{array}{l}\text { Direct PV sales to traders, } \\
\text { community engagement, } \\
\text { government support, available } \\
\text { energy data audit enables design }\end{array}$ \\
\hline
\end{tabular}

Source: author's compilation from (Allon, 2018)

\section{Methods}

This study started with a comprehensive review of off-grid electrification programs of many developing countries, sub-Saharan Africa and Nigeria. Optimization and simulations of energy resources were done using HOMER $^{\text {TM }}$ model. Weather data was obtained using online resources from NASA, this helped in getting the actual wind speed, solar irradiation, humidity and temperature data from specific locations used in the study. The hydrology data used for this analysis was obtained from the flowrate data at lower Niger at Asaba-Onitsha axis (Mahé, Liénou, \& Adeaga, 2009). The Techno-economic analysis as shown in Figure 1 was done using local component prices obtained from Nigerian Electricity Regulatory Commission (NERC), and costs data from IPPs operating in the country. Electricity prices for different sites were based on the price from the electricity distribution company (Disco) operating in the region concerned. The prices were based on multi-year-tariff-order for 2017 tariff regime as approved by NERC (NERC, 2016). 


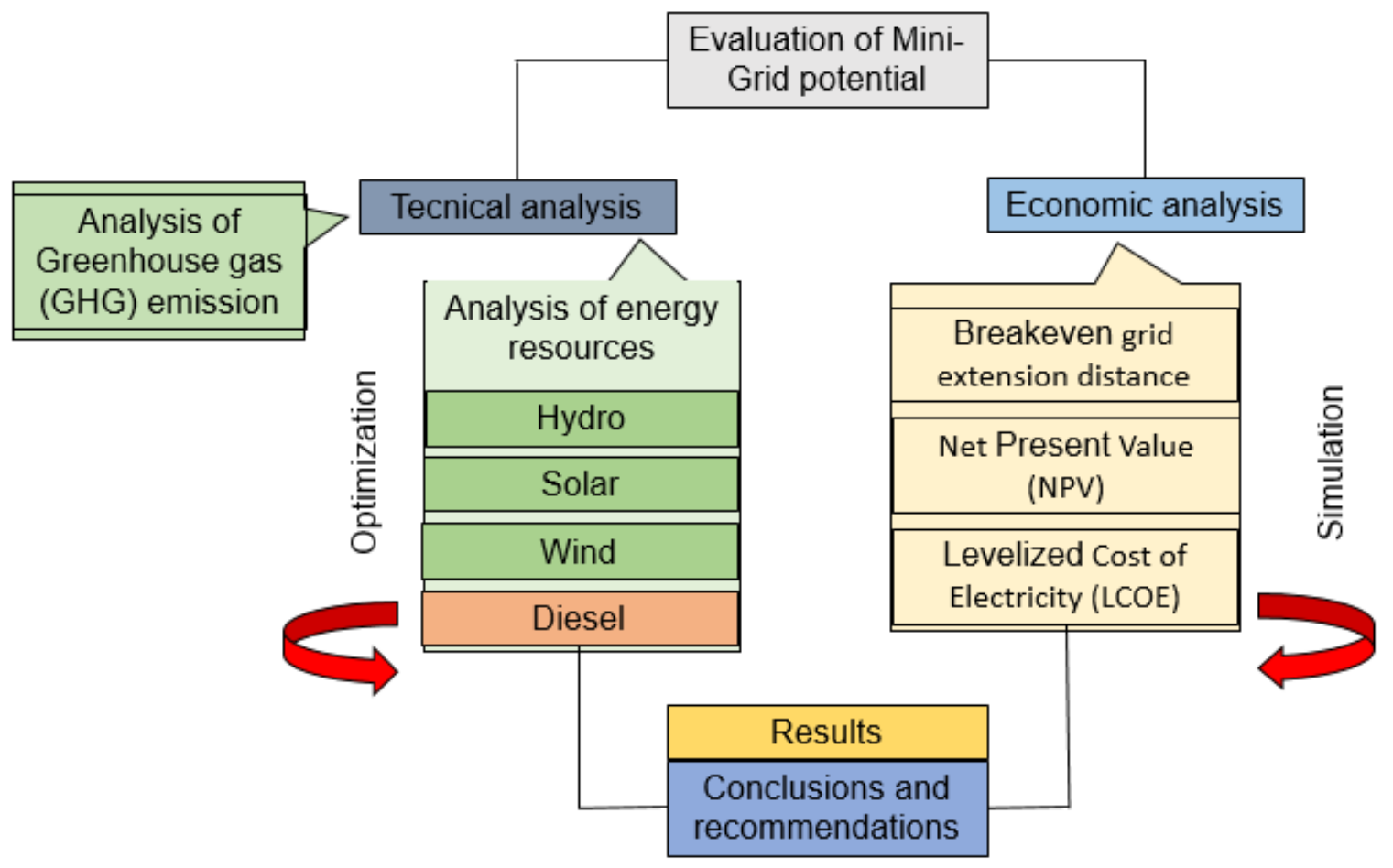

Figure 1. Work breakdown structure for the evaluation of mini-grid potential

\subsection{Economic Dimension of the Hybrid Mini-Grid}

Evaluation of the economic viability of the hybrid mini-grid systems were done using financial instruments such as the net present cost (NPC), levelized cost of electricity (LCOE), Initial Capital Cost (ICC), operating cost (OC), fuel consumption and breakeven grid extension distance (BED). The systems were ranked based on their NPC, however, LCOE gives an indication of the preferred energy mix in a specific location. LCOE gives an aggregate value of the cost of electricity (COE) production for mini-grid components. It measures projected life cycle costs and gives indication of economic viability based on technical and economic evaluation of projects. LCOE is a standard mainstream tool that has been used by many organizations in both public and private sectors for project viability analysis. Previous studies such as (Cervigni, Rogers, \& Hendrion, 2013), (Nfah, Ngundam, Vandenbergh, \& Schmid, 2008)(Sánchez, Torres, \& Kalid, 2015)(Zhou, Lou, Li, Lu, \& Yang, 2010), (Adaramola, Agelin-Chaab, \& Paul, 2014), (Rehman \& Al-Hadhrami, 2010), (Ley et al., 2014)(IRENA, 2018) have adopted LCOE in their analysis.

\subsection{Technical Dimension of the Hybrid Mini-Grid}

A load of $2000 \mathrm{kWh} /$ day for a hypothetical rural community of 300 households was used for the investigations in all locations. Renewable resources like solar, wind, hydro was simulated in hybrid with diesel fuel energy resources in various sites under investigation, energy generated from the hybrid mini-grids, state of charge of the batteries under operations, and electricity access were used as tools for evaluation of technical capabilities of the mini-grid. The cost data used for this study are as shown in Appendix A: Table 1.

\subsection{Greenhouse Gas Emission of the Hybrid Mini-Grid Systems}

Greenhouse gas (GHG) emission for each location were measured using yearly emission of Carbon Dioxide $\left(\mathrm{CO}_{2}\right)$, Carbon Monoxide (CO), Nitrogen Oxide $\left(\mathrm{NO}_{2}\right)$, Particulate Matters (PM), Sulphur Dioxide $\left(\mathrm{SO}_{2}\right)$, and Unburned Hydrocarbons as indicators (UHC). The concern for the environment and the negative effects of climate change has made low carbon energy systems an indispensable and inevitable alternative for the provision of energy in the world. Suffice this to say that, even though some locations are more favorable for grid extension alternative, the need to reduce greenhouse gas emission makes it a compelling option.

\subsection{Study Areas}

The solar irradiation profiles and wind speeds for all the sites are as shown in Figure2-3 respectively. 
Solar Irradiation profile • Abuja •Bạma • Birnịn Kebbi • Enugu • Gưmel • Ibusạ • Jalingo • Jos • Lagos • Makưrdi • Port Harcourt 7.5

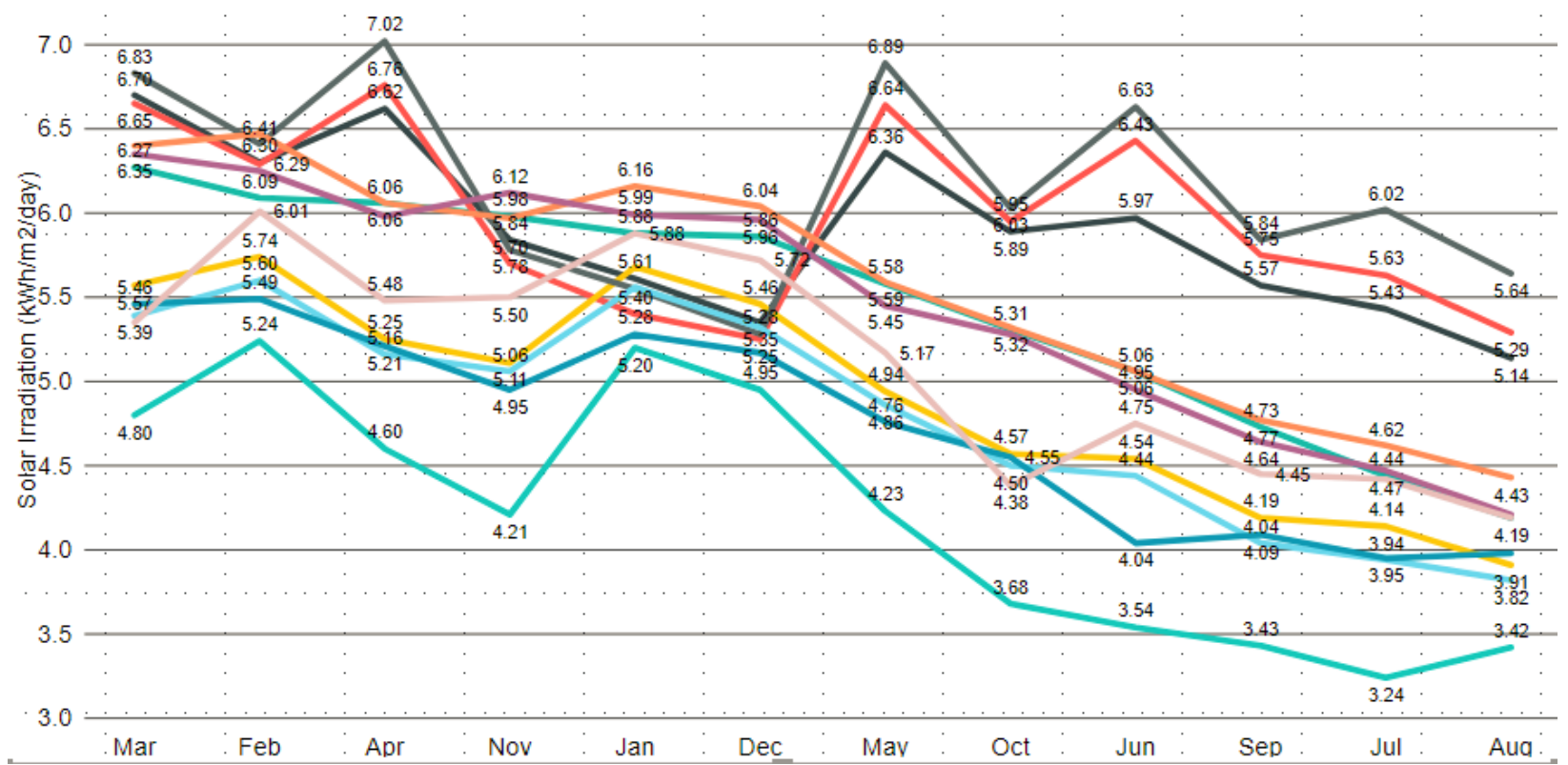

Figure 2. Solar irradiation profile of all sites investigated

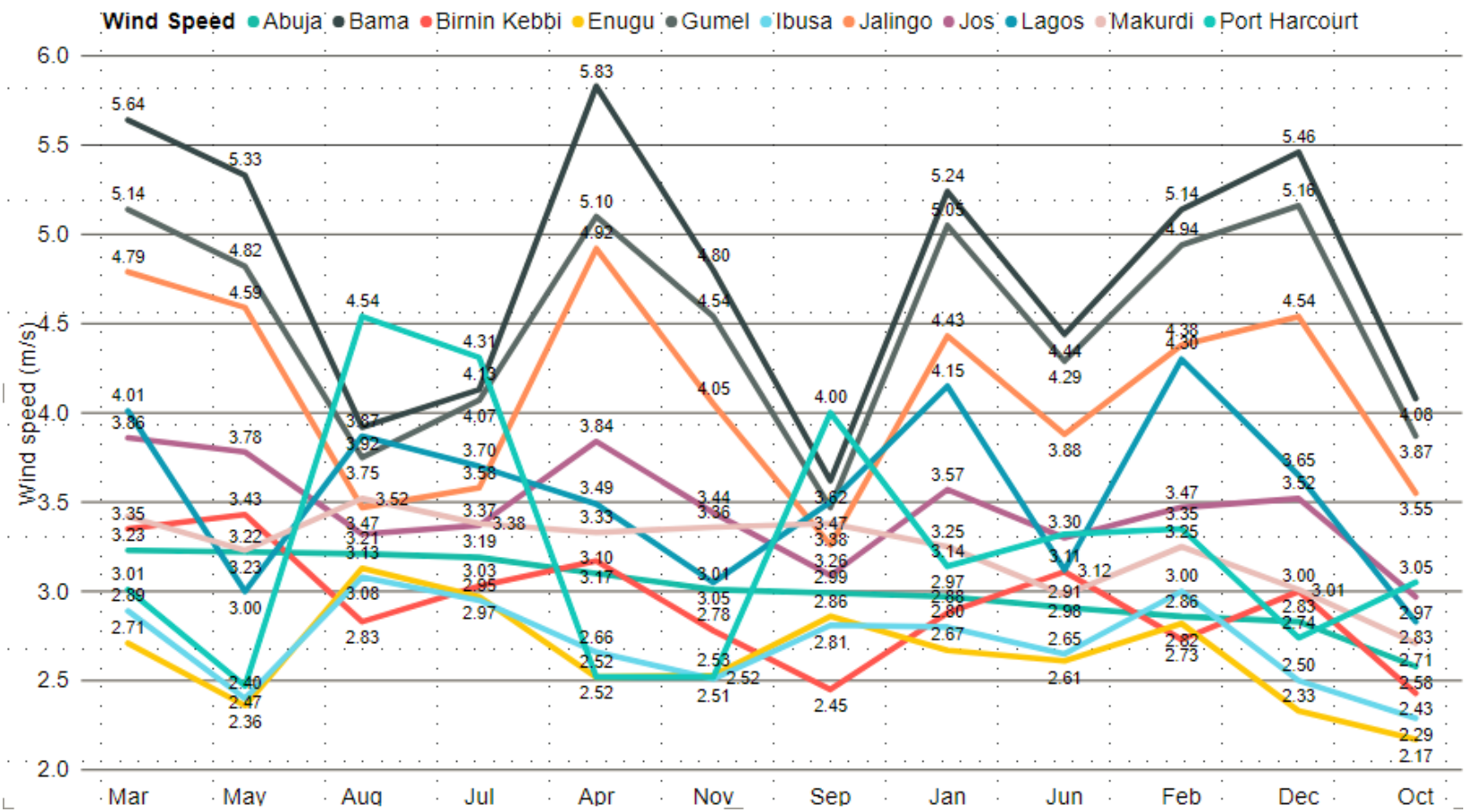

Figure 3. Wind speeds of all investigated sites

This paper investigated eleven sites in six geographical zones of Nigeria, these includes Ibusa also known as Igbuzor and Port Harcourt (South-South), Enugu (South East), Lagos (South West), Makurdi, Jalingo and Jos (North Central or Middle Belt), Abuja (Federal Capital Territory), Bama and Gumel (North East), and Birnin Kebbi (North West) regions. The site locations and electricity distribution companies operating within the regions are as shown in Figure 4, with their multiyear tariff order (MYTO) costs for different Discos operating in sites under investigation in each region. The tariff system classified under R3 (LV maximum demand 11/33 KV) in the MYTO document were used for the investigation (NERC, 2016). 
According to the World Climate Change Vulnerability Index, as quoted in the NDC (2016), Nigeria is one of the ten most climate-vulnerable countries, and Lagos is the tenth most vulnerable city in the world (Roche et al., 2017a).

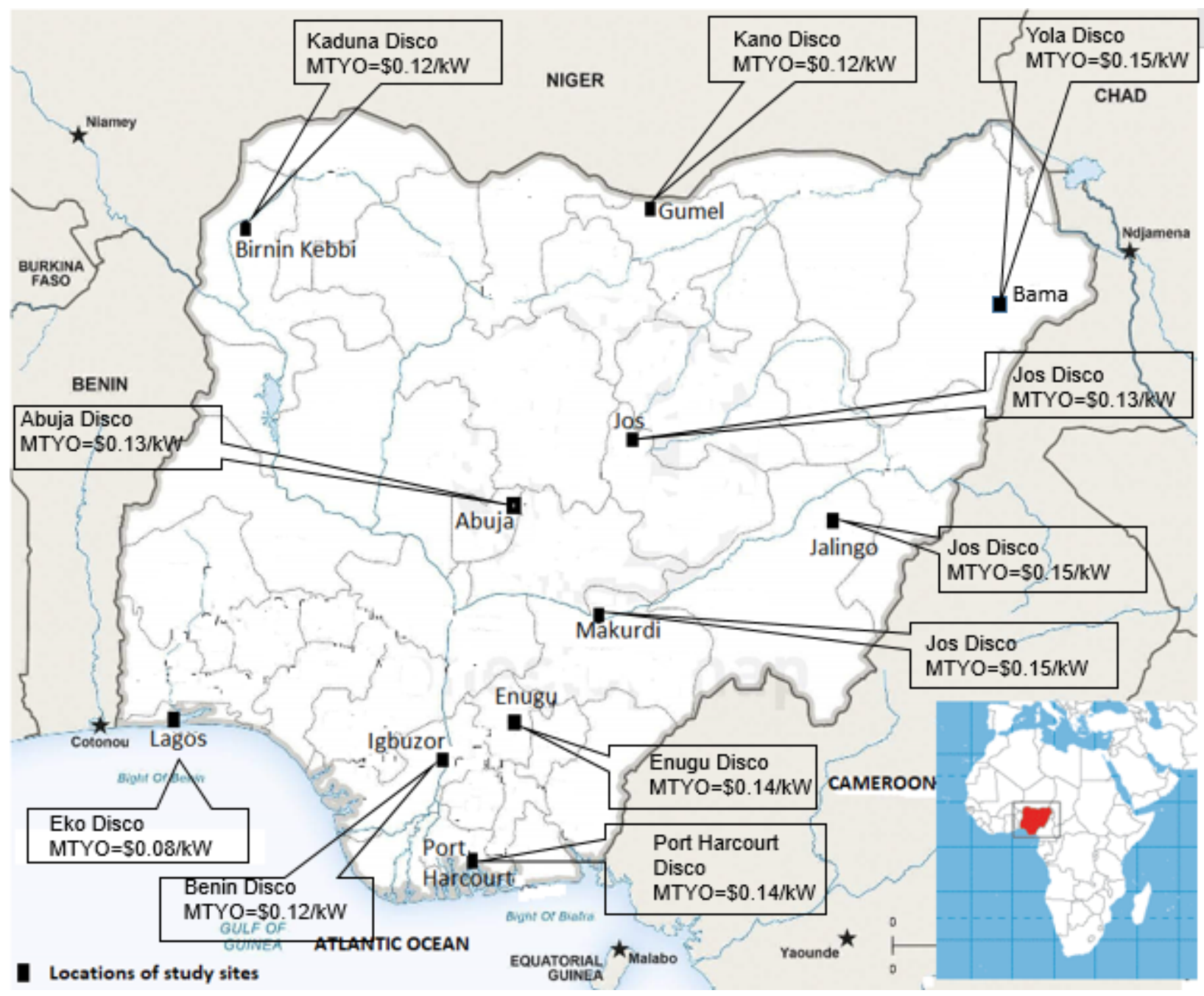

Figure 4. Investigated sites with their regional tariff charges

\subsection{Assumptions and Limitations of the Study}

To arrive at the results in this study some assumptions were made, and limitations that could have constrained our findings were encountered. To this extent, the results in this investigation is not absolute. Nevertheless, our findings provided information on what is expected when implementing mini-grid technology projects in Nigeria. It is assumed that all the sites have the same access to the hydrology data used. The foreign exchange is assumed to be $\mathrm{N} 350.00$ to $\$ 1.00$. The investigation used LCOE and NPC in ranking optimal technology solution for a specific location, this however is not enough to conclude on the best technology choice, other factors like population density, demand density, clustered or dispersed homesteads, cost of transportation, distance from sea and airports, geographical terrain, social and political situation in the communities under investigation etc. which were not taken into account in this study should be considered in order to accentuate holistically the vital elements before reaching a conclusion.

\section{Results}

The results are presented in line with the economic and technical dimensions of the investigation.

\subsection{Technical Dimensions of the Hybrid Mini-Grid}

The evaluation of technical dimensions of this paper takes into consideration the contributions of energy resources in various sites under investigation, energy generated from the hybrid mini-grids, rate of fuel 
consumption, state of charge of the batteries under operations, electricity access as parameters.

\subsubsection{Energy Contributions of Various Energy Resources to the Hybrid Mini-Grid}

Various energy resources namely, wind, hydro, solar, diesel were fed to the mini grid for the simulation of the optimal energy mix. The outcome for the locations investigated is as illustrated in Figure 5. It shows that solar energy is the most utilized energy resource in the mix. Most locations in the southern, middle belt and North-Western zones relied largely on solar to meet their energy needs, contributing over $80 \%$ to the mix, except for Jalingo (Middle Belt) and Lagos (South West) that contributes $72.5 \%$ and $76.3 \%$ respectively. Meanwhile, those in North-Eastern zone have comparative advantage with wind energy, even though the solar irradiation profile of this zone is one the highest in the sites investigated. Sites in Bama and Gumel contributes above $67 \%$ of wind energy in the mix.

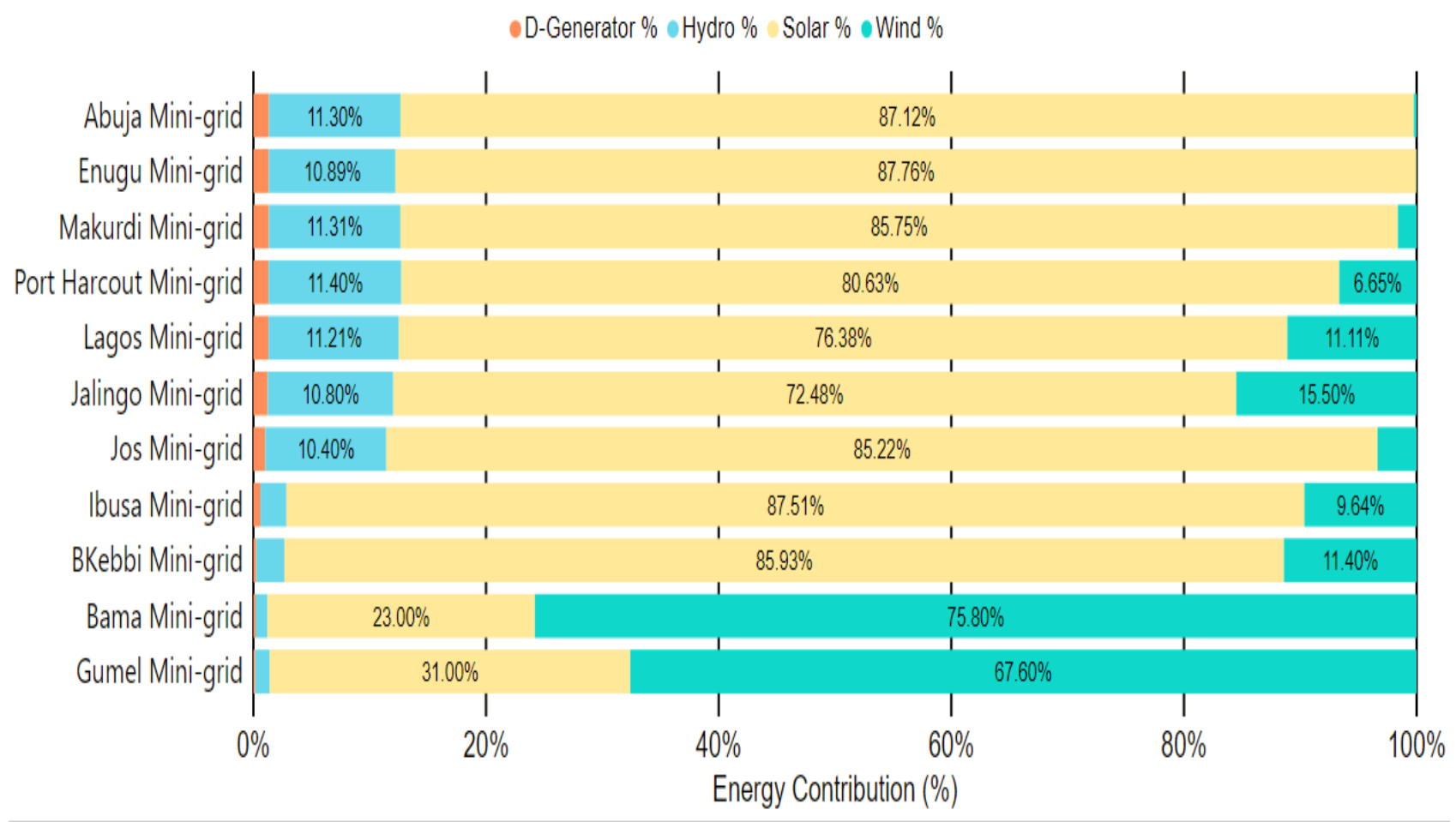

Figure 5. Contributions of various energy resources to the hybrid mini-grid

\subsubsection{Electrical Energy Output from the Hybrid Mini-Grid}

The electrical energy output from the mini-grid indicates that locations in the North East generated more energy per annum than the rest of the sites. Bama generated about 3,380,192 kWh/year of energy, which is the highest of all the sites investigated as seen in Figure 6. While Birnin Kebbi generated the least energy at 1,420,356 $\mathrm{kWh} /$ year, despite this, the energy generated was enough to meet the needs of the community with excess supply to the utility grid. In addition, locations such as Bama and Gumel (North East), Birnin Kebbi (North West) and Ibusa (South-South) were able to meet their loads with limited supply from the diesel generator. In the North-East sites, the average diesel consumption was about 1,700 L/year, while the consumption rate at Ibusa stood at 2,877 L/year. The fuel consumption rate was lowest at Birnin Kebbi with 1,126 L/year, while Enugu (South East) consumption was the highest at 6,661 L/year. The rest locations consumed an average of about $6,000 \mathrm{~L} /$ year. It shows that fuel consumption was high mostly in the months of April-September, which fall within rainy season characterized with overcast days Figure 7 . The reliability of power generated and supplied is indicated by the state of charge of the battery, which operated above $70 \%$ SOC on the average as shown in Figure 8 . 

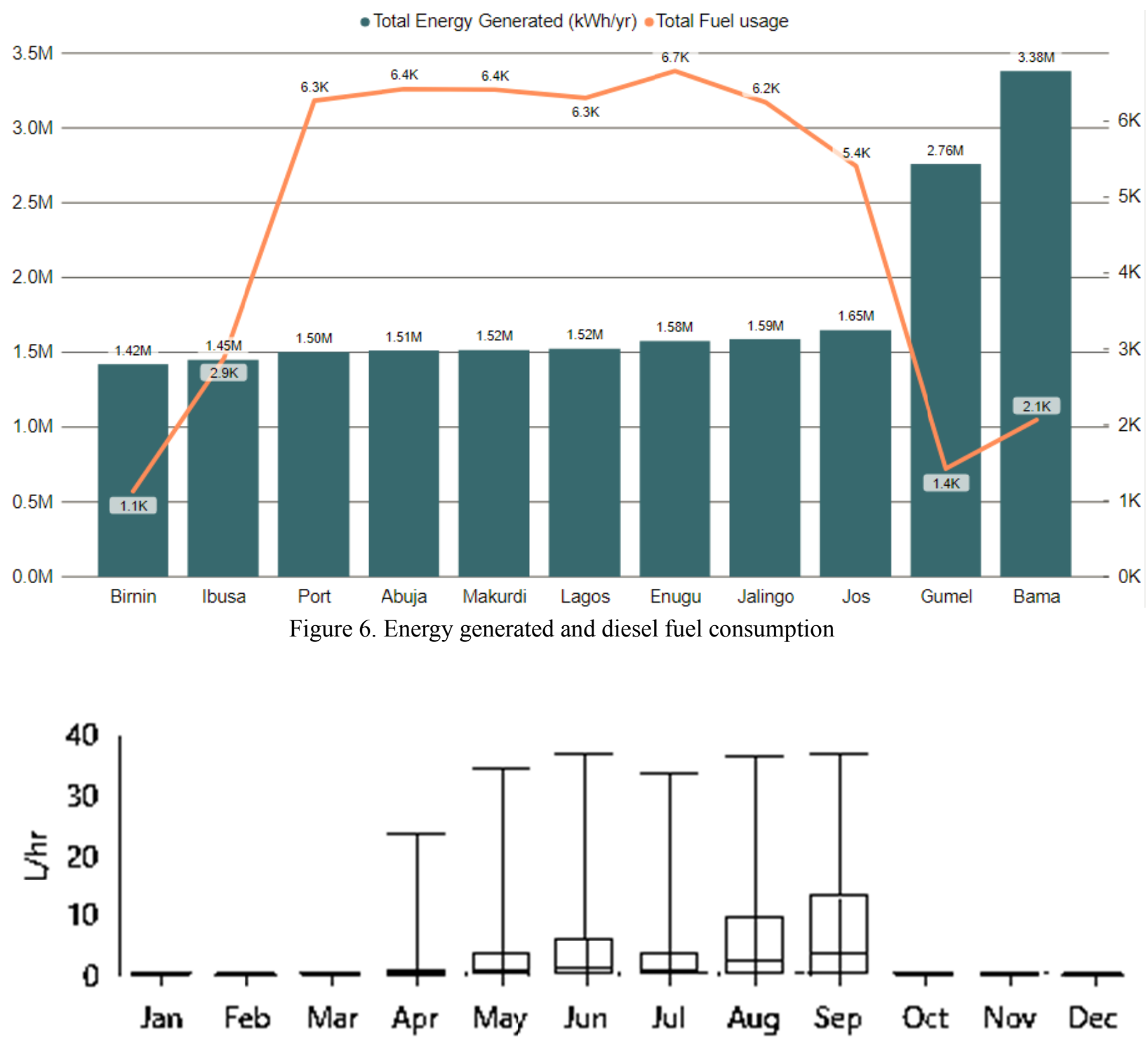

Figure 7. Fuel consumption profile for the investigated sites

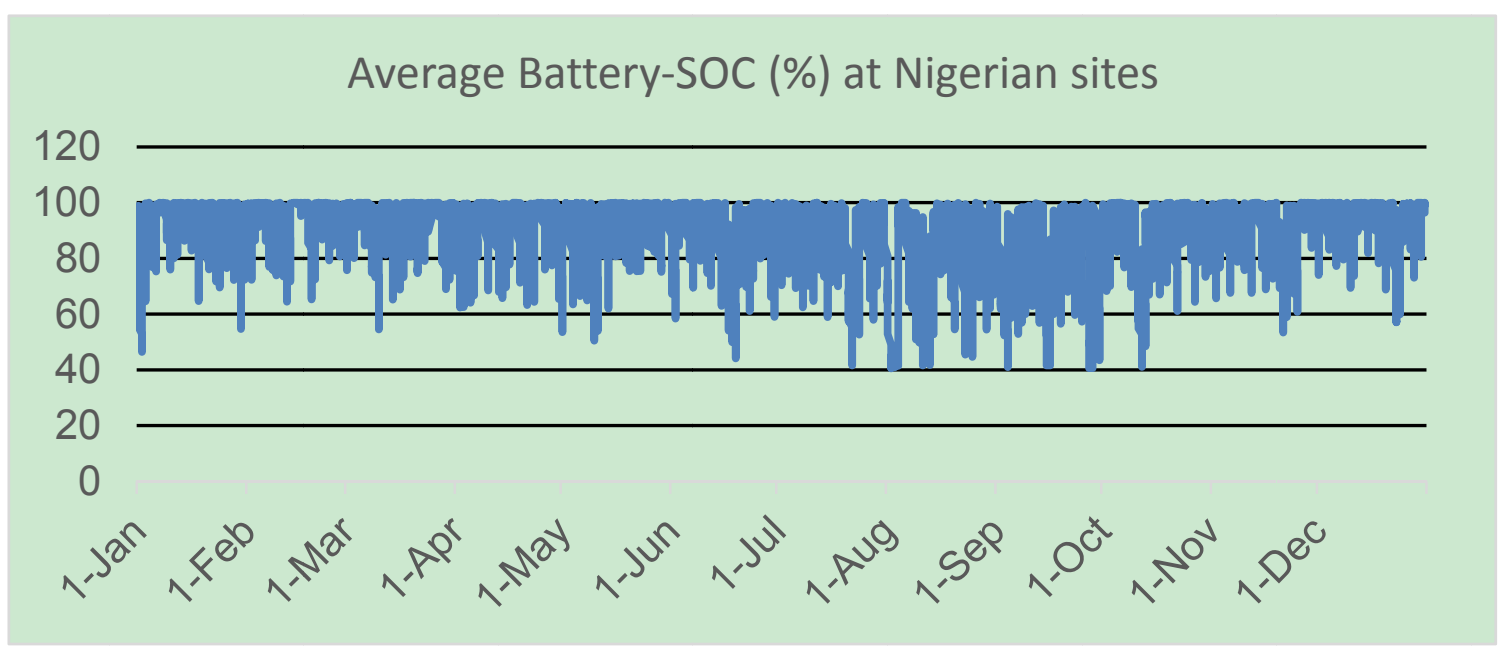

Figure 8. State of charge of the batteries during operation 


\subsubsection{Excess Energy Production from the Hybrid Systems}

The designed load for the communities under investigation was about $2000 \mathrm{kWh} /$ day. However, excess electricity occurs when production exceed the load. In the case of a standalone and island operated grid, excess electricity is often used by a dump load. Whereas, in a grid connected mini-grid excess electricity is fed into the utility grid. This situation makes a good case for proponents of net metering policy, which allows private generators of electricity to sale to the grid when they have excess and buy from the grid when there is a shortfall in their production. The sites in the North eastern part of the country generated more energy above their needs and have excess electricity above $70 \%$, while the rest locations have average excess electricity of about $40 \%$ as shown in Figure 9.

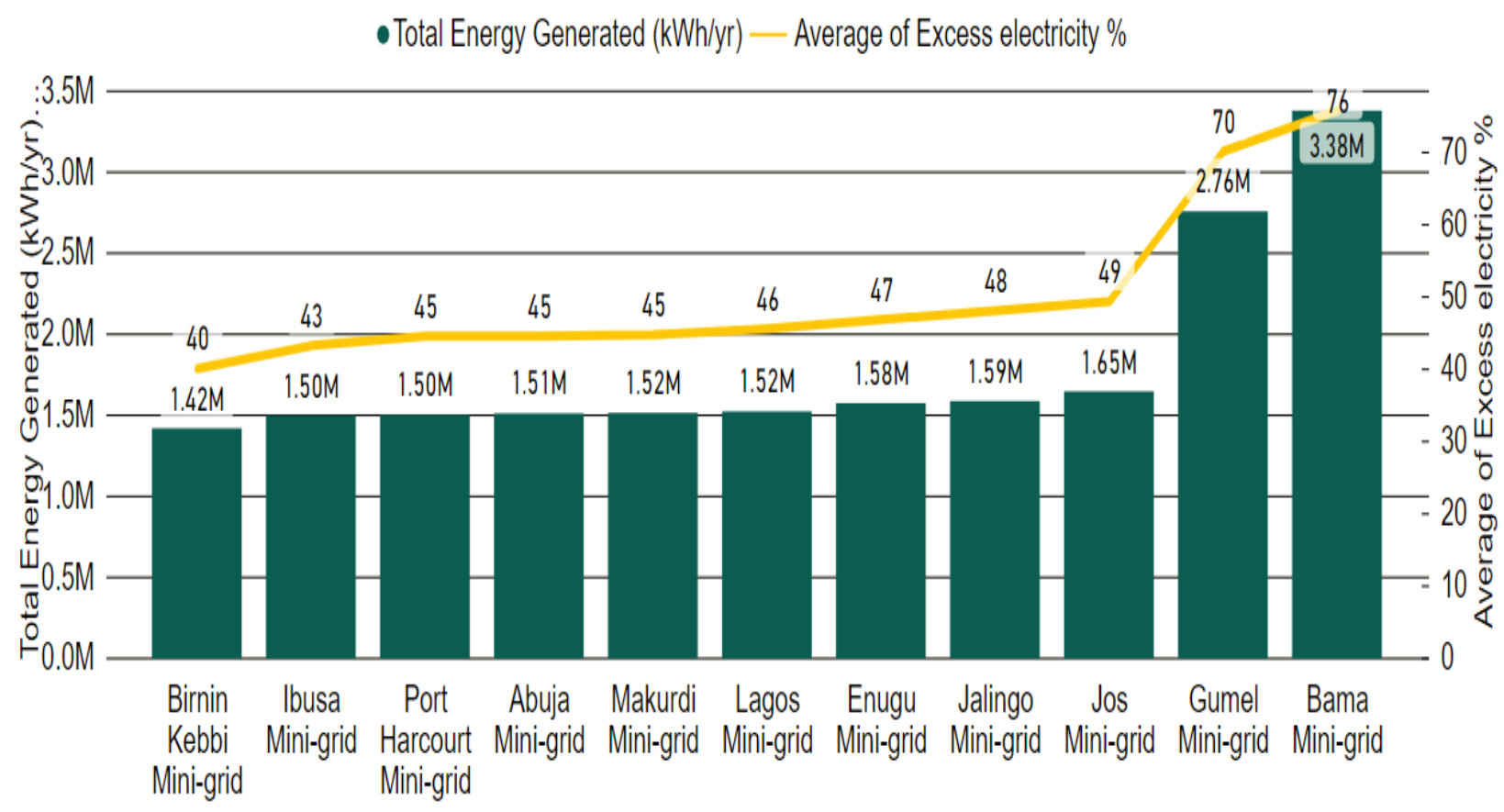

Figure 9. Generated and excess electricity for the hybrid mini-grid

\subsection{Economic Dimensions of the Hybrid Mini-Grid}

This section shows the analysis of the economic dimension of this study, it provides the results for the breakeven grid extension distance for the each of the locations investigated, Net present costs and the levelized cost of electricity.

\subsubsection{Breakeven Grid Extension Distance}

The breakeven grid extension distance (BGED) is the distance at which the net present cost of implementing a standalone mini-grid is equal to the net present cost of extending the utility grid. Optimization of data in the given locations shows that Lagos and Ibusa has the highest distance at $217 \mathrm{~km}$ and $155 \mathrm{~km}$ respectively as shown in Figure 10, which indicates that grid extension is mostly preferred in these locations. The closer the breakeven distance, the more preferred the mini-grid option. The negative breakeven grid extension distance obtained at Bama $(111 \mathrm{~km})$ and Gumel $(62 \mathrm{~km})$ is an indication that the optimal solution in these sites is the hybrid mini-grid. Apart from Jalingo, the analysis shows that the average BGED for the sites in southern and middle belt of the country is about $90 \mathrm{~km}$, which shows that grid extension is a friendlier option. The furthest breakeven grid extension distance (Lagos) for the sites investigated is as depicted in Figure 11. 


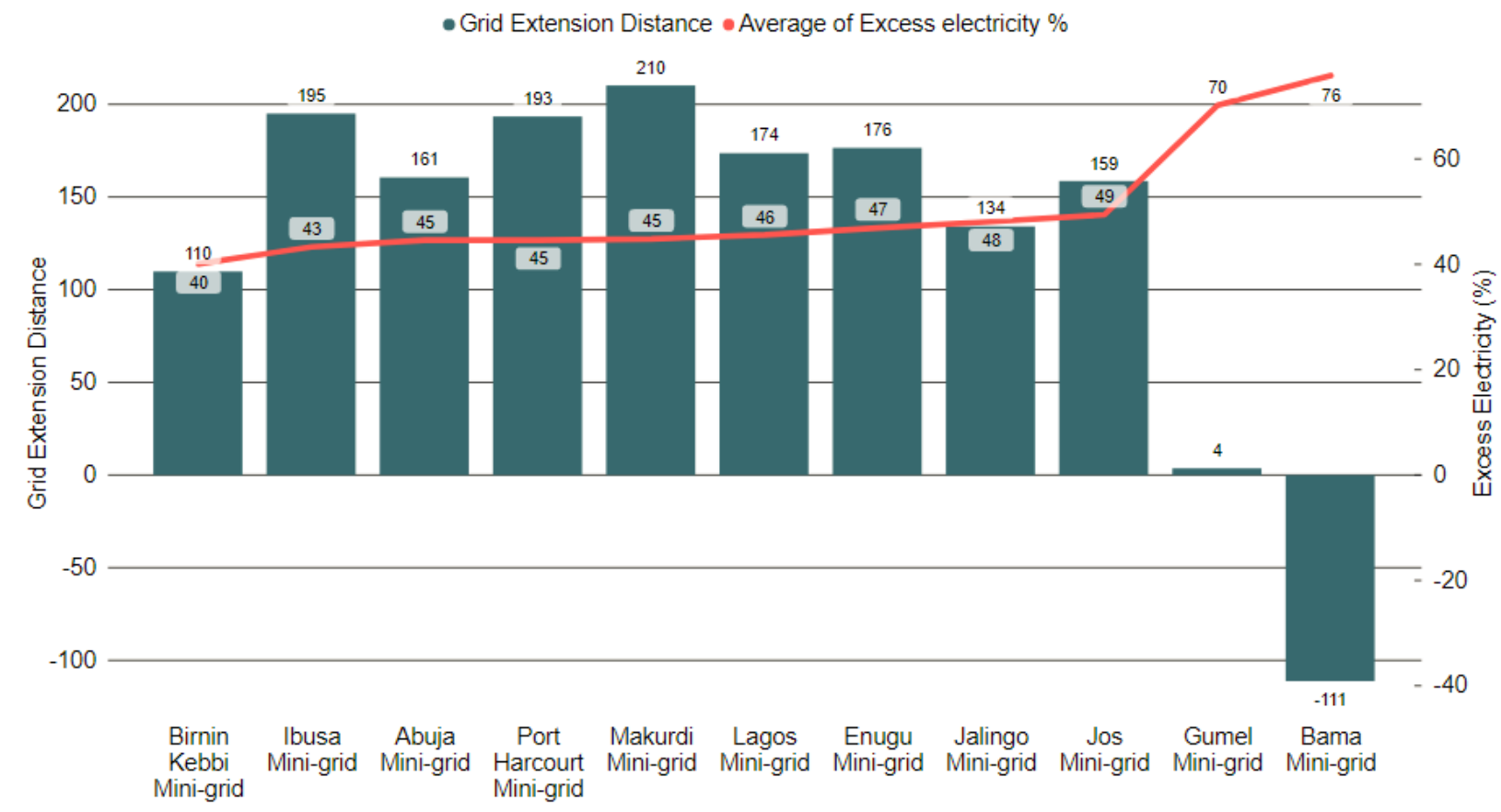

Figure 10. Breakeven grid extension distances for the investigated locations

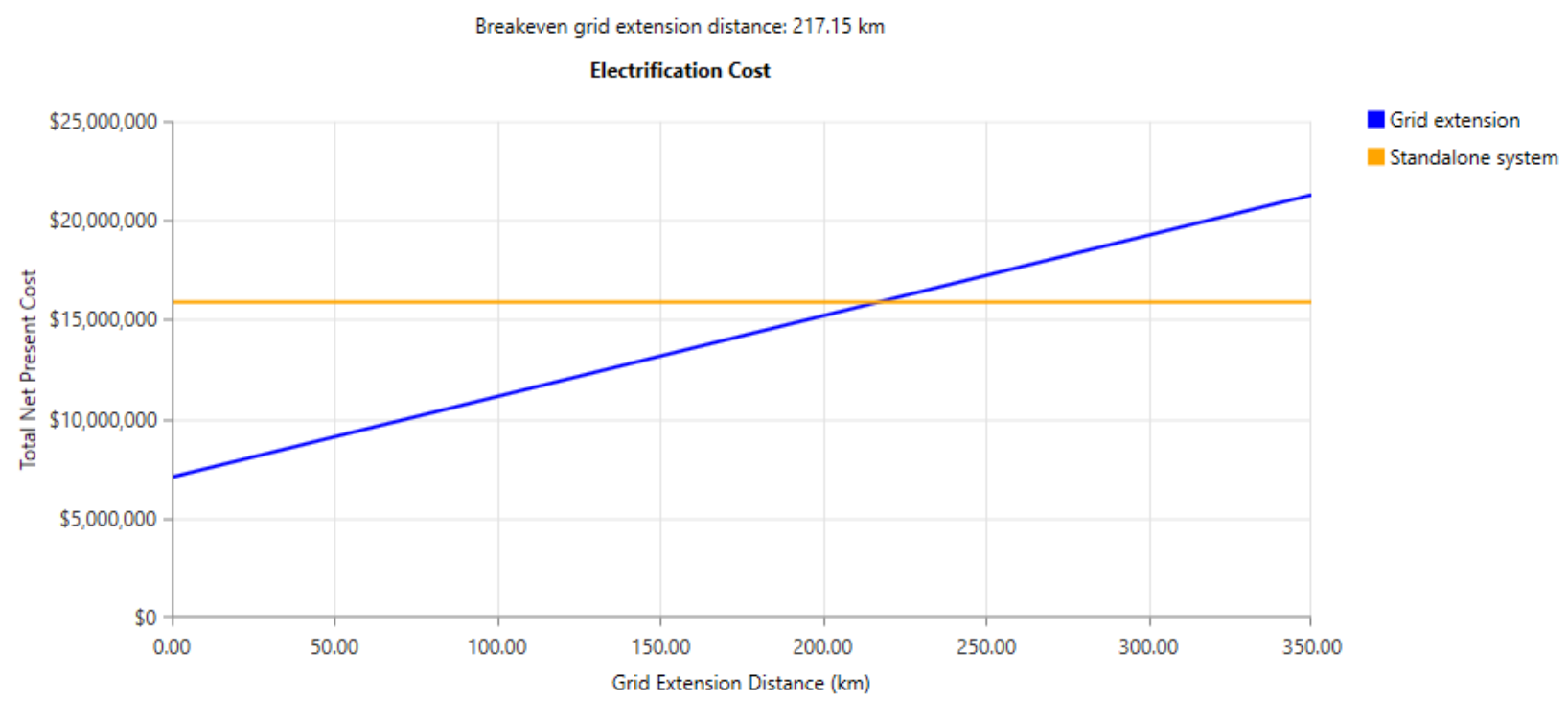

Figure 11. Breakeven Grid Extension Distance for Lagos

\subsubsection{Net Present Costs of the Investigated Sites}

According to HOMER ${ }^{\mathrm{TM}}$, the net present cost of a component is the present value of all the costs of installing and operating the Component over the project lifetime, minus the present value of all the revenues that it earns over the project lifetime. All the sites investigated indicates a positive net present cost which implies that setting up mini-grid in these locations could be a profitable venture. Despite the fact that locations in the North have higher generation capacity their NPC is lower than those in the South and middle belt of the country as shown in Figure 12. 


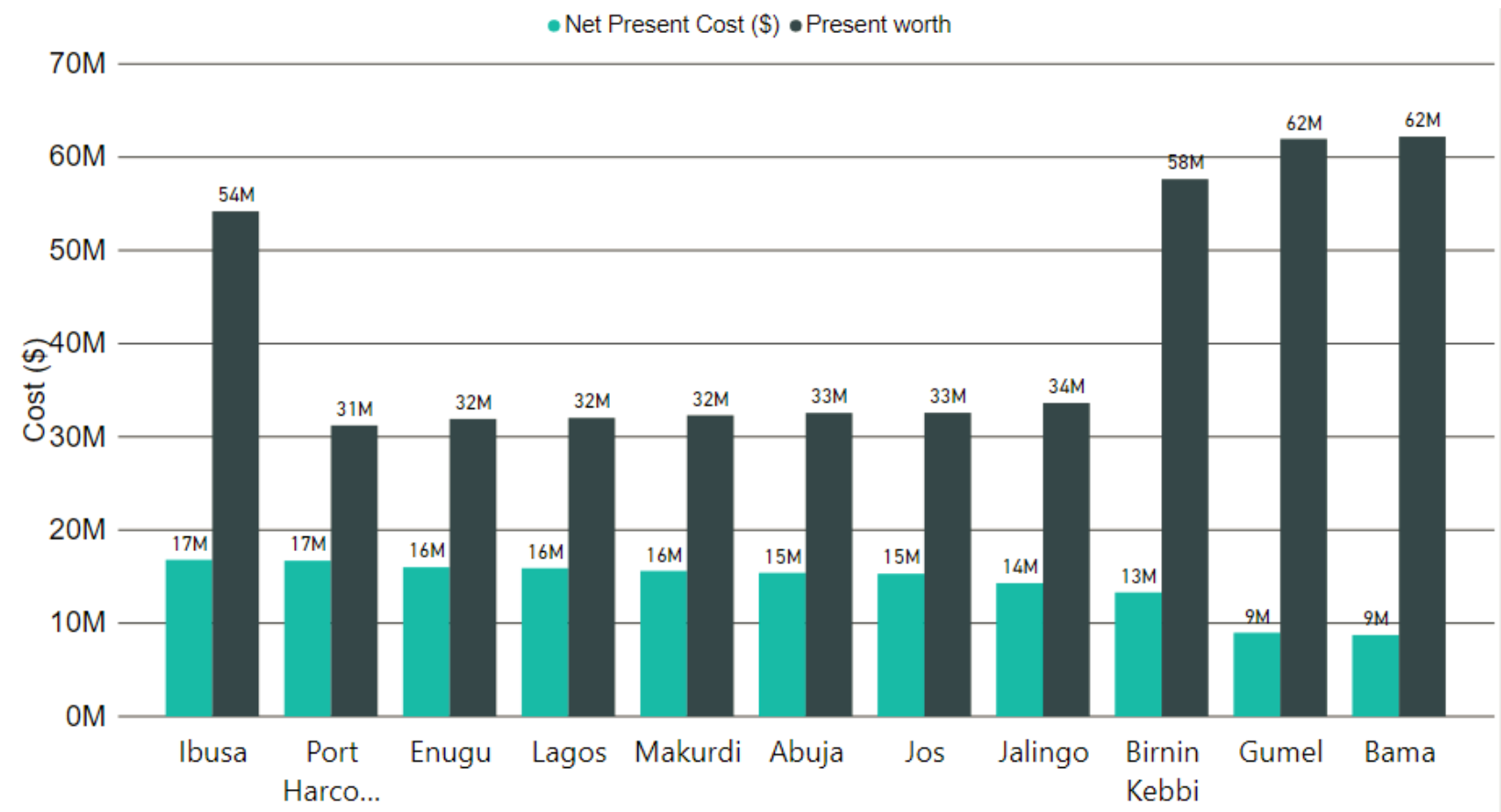

Figure 12. The net present cost and present worth of the hybrid mini-grids

\subsubsection{Levelized Cost of Electricity}

The analysis of the economic returns on investment indicates that not all the projects are viable to investors at the current regularized tariff. This was evaluated using LCOE as indicators. The results show that the LCOE for locations in southern and middle belt of the country have higher LCOE due primarily to more reliance on diesel fuel generator during overcast days. Port Harcourt had the highest LCOE with $\$ 0.86 / \mathrm{kWh}$, while Gumel and Bama had the lowest LCOE with $\$ 0.45 / \mathrm{kWh}$ as depicted in Figure 13.

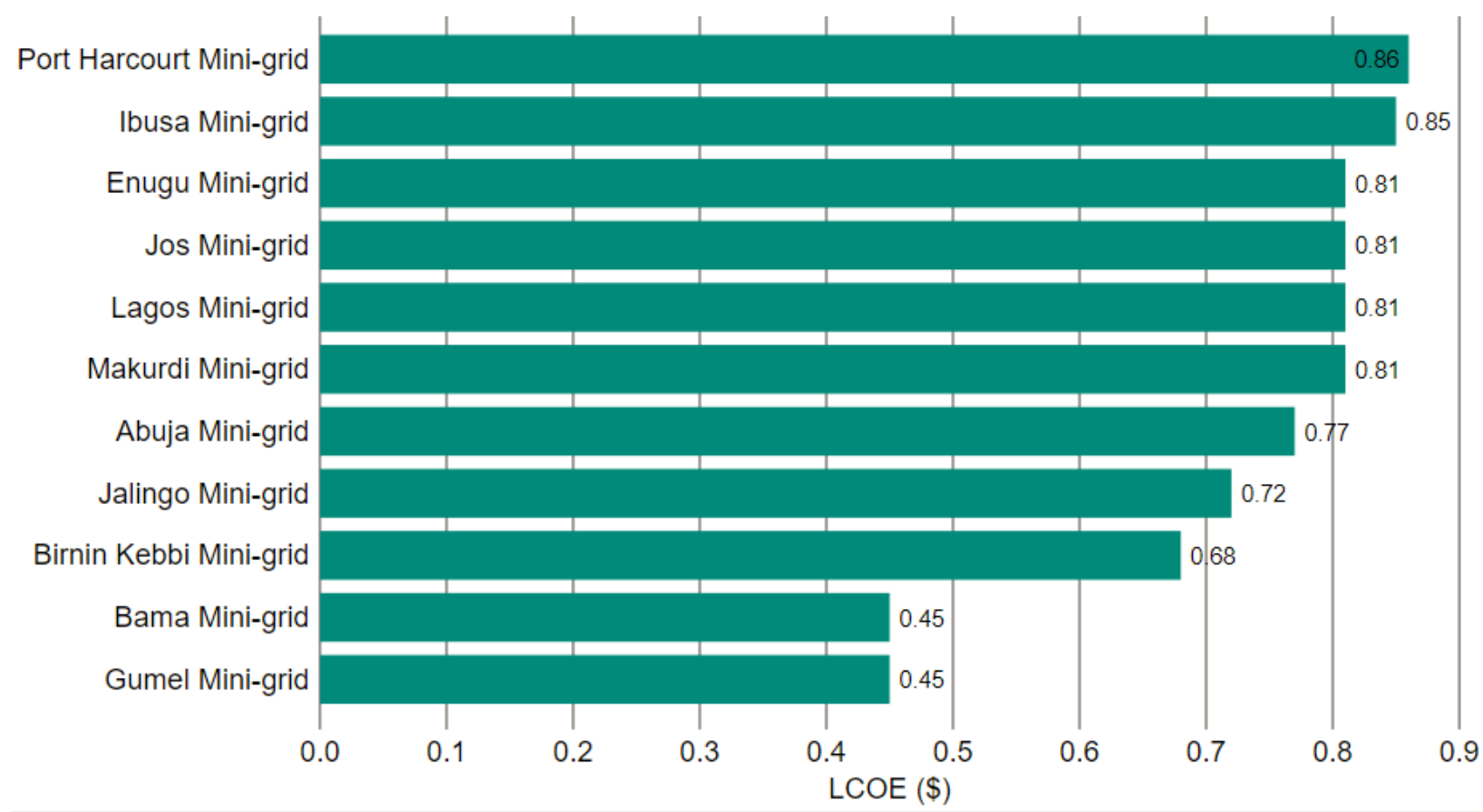

Figure 13. Levelized cost of electricity for the investigated sites 


\subsection{Greenhouse Gas Emission Profile for the Sites Investigated}

The environmental impacts of electricity production are treated as societal cost, and as such, greenhouse gas emissions resulting from electricity production is calculated as part of its externalities. The emission profile of the investigated sites shows that operation of hybrid min-grid in northern part of the country is more environmentally friendly. Locations like Bama, Gumel and Birnin Kebbi have lower carbon emission of about $3,500 \mathrm{~kg} / \mathrm{yr}$., apart from Ibusa (carbon emission 7,532 kg/year), other locations in the southern and middle belt of the country have $\mathrm{CO}_{2}$ emission above $8,000 \mathrm{~kg} /$ year. Enugu had the highest emission due to more reliance on diesel generator to meet supply because of limited input from other renewable energy sources as illustrated in Figure 14. There is no significant emission of particulate matters and unburned hydrocarbons, however, carbon monoxide, Sulphur dioxide, and nitrogen dioxide were emitted to varying degrees in different locations, following the same trend and proportion as the emission of $\mathrm{CO}_{2}$.

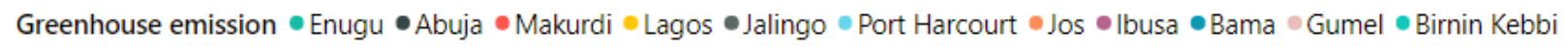

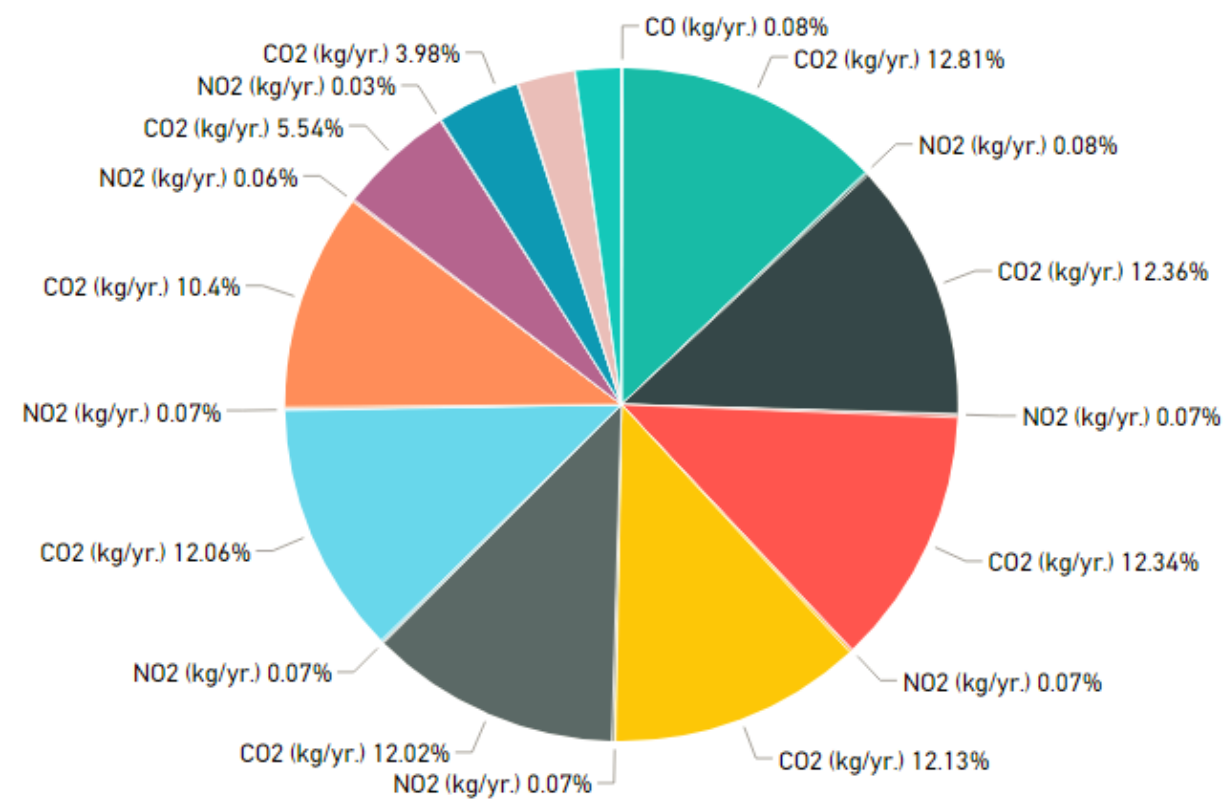

Figure 14. Emission of greenhouse gases in different locations

\section{Discussions}

Despite having high potential in both fossil and renewable energy resources, the electricity access in Nigeria is obnoxiously low. A situation that has compelled citizens to resort to self-help through private generation of electricity using diesel and petrol generators. Working through the streets in urban and some affluent rural settlements one is often confronted with cacophony of noises coming from captive generators of electricity, constituting noise and environmental pollutions. It has been reported that off-grid generations through polluting diesel and petrol generators is estimated to be around 60 million in the country (Roche, Ude, \& Donald-Ofoegbu, 2017b). A raconteur once quipped that having a generator is a status symbol in Nigeria "it is a measure of how well you are better than your neighbor", comedians have many jokes about the utility network, the acronym NEPA was changed to "never expect power always" and the power holding company is taken literally to mean that the government is holding power from the people. That said, diesel generators have become indispensable due to their support for businesses and lighting after hours. According to (Roche et al., 2017a), it is estimated that 8-14 GW of decentralized diesel generators are currently operational in the country, in Africa, Nigeria leads as the highest generator importer and a significant importer worldwide, it is further estimated that the total import figure per annum is about US\$ 112 million. Despite the reforms that has been carried out in the energy sector, the target of meeting energy needs of the growing population is still farfetched. The realization of the objectives of visions 2030:30:30 is very much unlikely with the seemingly lackluster activities in the energy sector. To bridge this gap, an intensive growth trajectory akin to those countries with success stories must be followed. As it stands, electricity access is disproportionately low in rural regions (34\%) compared with urban 
regions (86\%), albeit grappling with intermittent supply. This situation is common in most countries in ECOWAS region with the exception of Cape Verde and Ghana that has achieved above $80 \%$ access to electricity as shown in Figure 15.

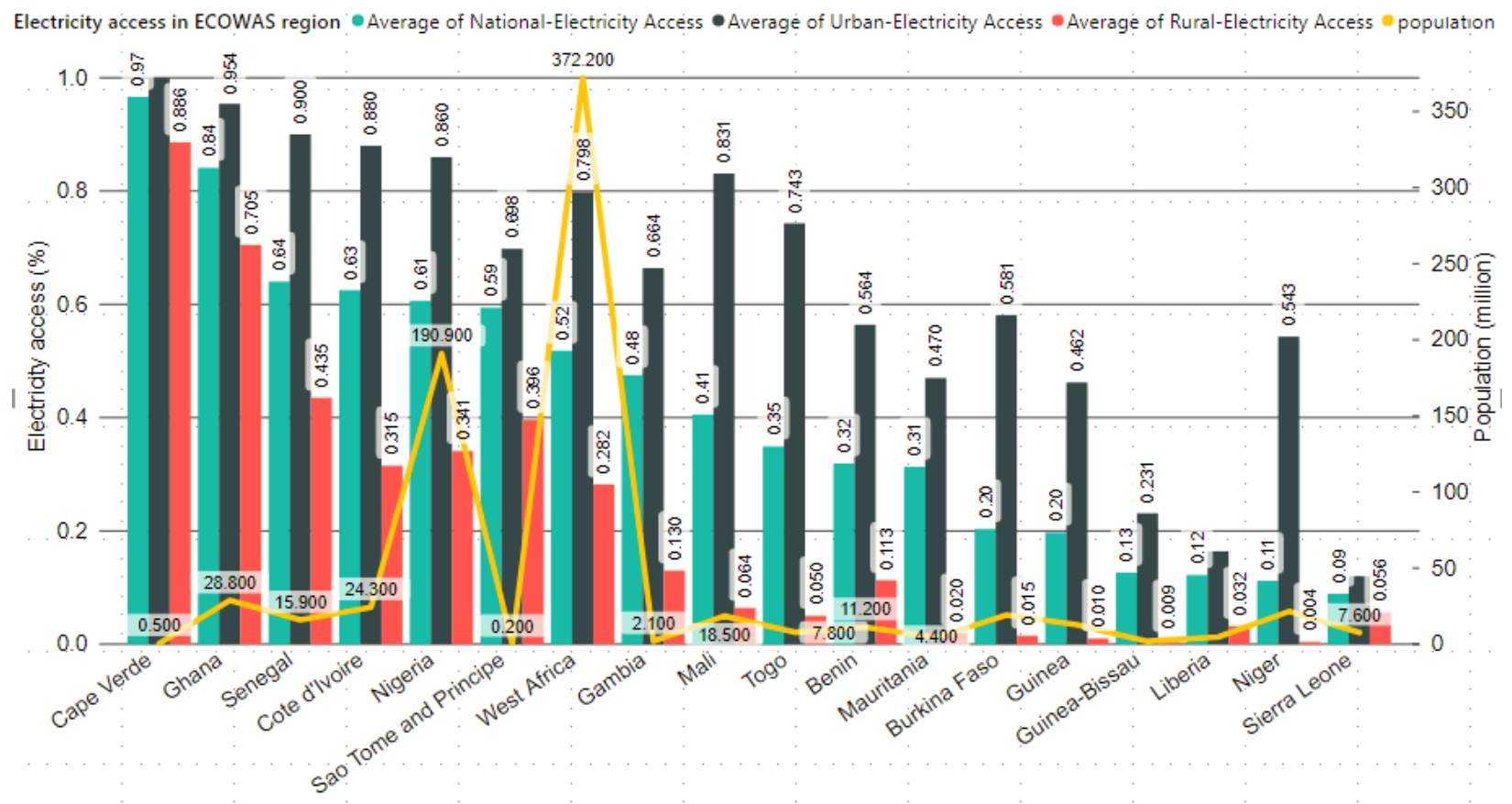

Figure 15. Electricity access in ECOWAS region

Source: Authors compilation from (IEA, 2017).

The findings in this investigation shows that different locations in different regions of the country are uniquely important for generation of renewable energy electricity into the national utility grid. However, on the average grid extension is mostly favored both from technical and economic point of view. This is at variance with the position of (Ohiare, 2015), that projected that by $2030,98 \%$ of the un-electrified segment of the population will be viable for the grid, while only $2 \%$ will be mini-grid compatible. Further investigations are required to analyze the whole potential in its entirety, such that geographical conditions, economic and socio-political situation on the sites are brought into perspective, without which, any conclusion reached will remain conclusively anecdotal.

The electric energy generation profile indicates that solar energy is the dominant renewable resource that is mostly utilized in all the locations investigated, contributing more than $80 \%$ in the mix, mostly in the southern and middle belt regions. This shows that the country has good potential for the implementation of solar-based standalone and grid connected systems. However, the situation in northern part indicates that even when Gumel and Bama have the highest solar irradiation profiles (Figure 2), wind energy contributed above $75 \%$ in their mini-grids while utilizing about $25 \%$ solar energy contribution, this is because the NPC for wind energy technology is favored more in these sites. A unique discovery is the findings at Ibusa, where wind energy contributed up to $10 \%$ in the mix. This is contrary to the mainstream opinion and widespread perception among stakeholders that wind technology does not hold high potential in the country, and mostly in the southern region. The finding is totally aligned with the conclusions of ((IRENA, 2016)), (Ichord, Jr., 2016), that West African region have great potentials for solar and wind energy systems. On the average hydropower contributed about $10 \%$ energy in most of the southern sites, apart from Ibusa where wind power had comparative advantage. Diesel generators were sparingly used in almost all the locations but for Enugu site that had the highest use, this was due to low wind speed in this location, Birnin Kebbi site had the least use of diesel fuel. The reliability and stability of electricity generated is reflected in the state of charge of the batteries, which operated within their voltage controlled thresholds in all the sites as seen in Figure 8. The power generated met the loads as designed in all sites with excess electricity, apart from meeting the local loads, private power producers could be able to feed excess power to the utility grid.

The economic analysis suggests that sites in the northern part of the country, such as Bama and Gumel are more 
favored for implementation of standalone hybrid mini-grid in terms of their breakeven grid extension distances. The negative values for breakeven distance obtained indicates that the standalone system is a better alternative than grid extension at these sites. Locations like Ibusa and Lagos are more inclined for grid extension than standalone systems. Other sites had breakeven distances above $65 \mathrm{~km}$ apart from Jalingo with $25 \mathrm{~km}$. The analysis suggests that Gumel and Bama have lower NPC than other sites. The LCOE obtained ranges from $\$ 0.45$ to $\$ 0.86$ per $\mathrm{kWh}$, which differ from the position of ((IRENA, 2016)). Various reports have obtained different values for LCOE in different locations. According to IRENA, the current costs for mini-grids are between USD $0.47 / \mathrm{kWh}$ and USD $0.92 / \mathrm{kWh}$. While (IRENA, 2012), (The World Bank, 2013) posit that the cost of electricity from PV and hybrid PV-wind-diesel systems are in the range of $\$ 0.30 / \mathrm{kWh}$ and $\$ 0.22 / \mathrm{kWh}$, respectively.

The greenhouse gas emission profiles obtained from the sites is consistent with the objectives of UNFCCC conference of parties (COP21) and RIO+20 summit, though the emissions from street, household and industry captive generators have not been quantified, it far outstrips the minimal emissions from the investigated sited as indicated in Figure 14. This study provides a guide for decision making on project implementations and choice of technology for specific locations in Nigeria.

\section{Conclusions}

This study explores the prospect of increasing electricity access in Nigeria through utilization of locally available renewable energy resources, the outcome from this study could be extrapolated to other developing economies. The strength of the study is on its reliance on local costs data for components and online weather data from NASA that provided information on specific locations against the classical use of information from nearby weather stations. Our findings are provided in bullet points as follows.

- The study shows that Nigeria has high potential for meeting her energy needs using solar technology systems. All sites investigated have significant input from solar PV system in the hybrid mini-grid with other energy resources.

- Contrary to the wide spread perception that wind technology is not suitable for Nigeria, mostly in the southern part, the investigation at Ibusa site provided a counter narrative, wind energy technology contributed about $10 \%$ in the energy mix which helped in reducing the environmental impact, because of less reliance on diesel generators.

- To overcome the weakness in the transmission corridor, there is a need to embark on an ambitious electrification program in the country using embedded and distributed generations close to the load taking advantage of the opportunity provided by centralized and decentralized low carbon technology systems.

- The protracted shortfall in electricity generation in the country resulting from shortage of gas supply could be augmented with the inputs from renewable resources in the energy matrix.

- The greenhouse gas emission profiles for the locations investigated shows that a hybrid mini-grid could have less negative environmental impact in northern part of the country than in the southern and middle belt due to less reliance on diesel generators to meet shortfalls.

- Southern and middle belt part of the country are more favourable to grid extension, considering their breakeven grid extension distances and other investigated economic indices, such as NPC, Breakeven grid extension distance and LCOE.

- The findings further show the comparative advantages for a hybrid mini-grid in the northern Nigeria than the southern and middle belt parts of the country.

\section{Recommendations}

This investigation shows that there is a need for the government of Nigeria to initiate and implement policies that supports robust off-grid electrification program to fast-track improvement of the electricity access in the country. To achieve this, it is recommended that there should be a policy shift from too much emphasis on reinforcing the fossil base grid to a more sustainable and efficient alternative renewable energy base systems. In addition, actions should move from boardrooms, policy documents, seminars, workshops, and highfalutin talks to the fields, to meet the target and goals of vision 2030:30. We hope that this investigation could spur more scientific and scholarly research on how to unravel the challenges of increasing electricity access in many developing countries with low electricity access.

\section{Acknowledgement}

We thank the members of academic and non-academic staff of the faculty of Operations and Quality 
Management and Electrical and Electronics Engineering Technology, University of Johannesburg, South Africa for facilitating and providing the enabling environment for the conclusion of this manuscript.

\section{References}

Adaramola, M. S., Agelin-Chaab, M., \& Paul, S. S. (2014). Analysis of hybrid energy systems for application in southern Ghana. Energy Conversion and Management. https://doi.org/10.1016/j.enconman.2014.08.029

Azimoh, C. L., Dzobo, L., \& Mbohwa, C. (2018). Investigation of net metering as a tool for increasing electricity access in developing countries. In 2017 IEEE Electrical Power and Energy Conference, EPEC 2017. https://doi.org/10.1109/EPEC.2017.8286187

Azimoh, C. L., Klintenberg, P., Mbohwa, C., \& Wallin, F. (2017). Replicability and scalability of mini-grid solution to rural electrification programs in sub-Saharan Africa. Renewable Energy, 106. https://doi.org/10.1016/j.renene.2017.01.017

Bhattacharyya, S. C., \& Palit, D. (2016). Mini-grid based off-grid electrification to enhance electricity access in developing countries: What policies may be required? Energy Policy. https://doi.org/10.1016/j.enpol.2016.04.010

Cervigni, R., Rogers, J. A., \& Henrion, M. (n.d.). Low-Carbon Development Opportunities for Nigeria.

DME. (2008). New and Renewable Energy New and Renewable Energy.

NERC. (2016). MYTO-2015 Distribution Tariffs ( 2015-2024) Effective 1 st February 2016 Tariff classes, (February), 1-14.

Ferguson, R., Wilkinson, W., \& Hill, R. (2000). Electricity use and economic development. Energy Policy. https://doi.org/10.1016/S0301-4215(00)00081-1

Fitzgerald, S., \& Voege, D. (2010). Renewable Energy Technologies: Cost Analysis Series. Wind Power. Volume 1: Power Sector, issue 5/5. Internation Renewable Energy Agecy (IRENA), June 2012.

Ichord, Jr., R. F. (2016). Transforming the Power Sector in Developing Countries.

IEA. (2017). Energy Access Outlook 2017: From poverty to prosperity. OECD»IEA. https://doi.org/10.1098/rspb.2002.2297

Impact Energy : Case Studies of Successful Off Grid Energy Businesses in Research conducted by : (n.d.).

IRENA (2016), Innovation Outlook: Renewable Mini-grids, International Renewable Energy Agency, Abu Dhabi..

IRENA. (2016). Investment Opportunities in West Africa. Suitability Maps for Grid-Connected and Off-Grid Solar and Wind Projects, $24 . \quad$ Retrieved from http://www.irena.org/DocumentDownloads/Publications/IRENA_Atlas_investment_Latin_America_2016. pdf

IRENA. (2018). Renewable Power Generation Costs in 2017. International Renewable Energy Agency, (January), 160. https://doi.org/10.1007/SpringerReference_7300

Lau, K. Y., Yousof, M. F. M., Arshad, S. N. M., Anwari, M., \& Yatim, A. H. M. (2010). Performance analysis of hybrid photovoltaic/diesel energy system under Malaysian conditions. Energy. https://doi.org/10.1016/j.energy.2010.04.008

Ley, K., Gaines, J., \& Ghatikar, A. (2014). The Nigerian Energy Sector - an Overview with a Special Emphasis on a Special Emphasis on Renewable Energy, Energy Efficiency and Rurual Electrification. Internationale Zusammenarbeit (GIZ) GmbH.

Longe, O. M., Rao, N. D., Omowole, F., Oluwalami, A. S., \& Oni, O. T. (2017). A Case Study on Off-grid Microgrid for Universal Electricity Access in the Eastern Cape of South Africa. International Journal or Energy Engineering, 7(2), 55-63. https://doi.org/10.5923/j.ijee.20170702.03

Nfah, E. M., Ngundam, J. M., Vandenbergh, M., \& Schmid, J. (2008). Simulation of off-grid generation options for remote villages in Cameroon. Renewable Energy, 33(5), $1064-1072$. https://doi.org/10.1016/j.renene.2007.05.045

Nigeria National Bureau of Statistics. (2017). Automotive Gas Oil ( Diesel ) Price Watch, (JANUARY).

Nowak, A. (2009.). Goals of this Course. https://doi.org/10.1016/j.tsf.2006.01.019

Ohiare, S. (2015). Expanding electricity access to all in Nigeria: a spatial planning and cost analysis. Energy, 
Sustainability and Society. https://doi.org/10.1186/s13705-015-0037-9

Okpukpara, E., \& Ibiyemi, T. (2016). Technical review of Nigeria’s 2016 Mini-Grid regulation. Heinrich Boell Foundation October 30, 2016 report.

Pereira, M. G., Freitas, M. A. V., \& da Silva, N. F. (2010). Rural electrification and energy poverty: Empirical evidences from Brazil. Renewable and Sustainable Energy Reviews. https://doi.org/10.1016/j.rser.2009.12.013

Ptfp \& Pacp. (2010). Federal Republic of Nigeria for Power Sector To Achieve Stable Power Supply ).

Pueyo, A., Bawakyillenuo, S., \& Osiolo, H. (2016). ID, (190).

Rehman, S., \& Al-Hadhrami, L. M. (2010). Study of a solar PV-diesel-battery hybrid power system for a remotely located population near Rafha, Saudi Arabia. Energy, 35(12), 4986-4995. https://doi.org/10.1016/j.energy.2010.08.025

Roche, M.;, Ude, N. ; \& Donald-Ofoegbu, I. (2017a). True Cost of Electricity: Comparison of Costs of Electricity Generation in Nigeria. Nigerian Economic Summit Group and Heinrich Böll Stiftung Nigeria.

Roche, M.;, Ude, N. ; \& Donald-Ofoegbu, I. (2017b). True Cost of Electricity: Comparison of Costs of Electricity Generation in Nigeria. Nigerian Economic Summit Group and Heinrich Böll Stiftung Nigeria, (June), 1-34. Retrieved from https://ng.boell.org/sites/default/files/true_cost_of_power_technical_report_final.pdf

Sánchez, A. S., Torres, E. A., \& Kalid, R. A. (2015). Renewable energy generation for the rural electrification of isolated communities in the Amazon Region. Renewable and Sustainable Energy Reviews. https://doi.org/10.1016/j.rser.2015.04.075

Sector, V. P. (2012). Renewable Energy Technologies: Cost Analysis Series. Hydro Power. Volume 1: Power Sector, issue 3/5. Internation Renewable Energy Agecy (IRENA), June 2012. .

Sector, V. P. (2012). Renewable Energy Technologies: Cost Analysis Series. Solar Photovoltaics. Volume 1: Power Sector, issue 4/5. Internation Renewable Energy Agecy (IRENA), June 2012.

The World Bank. (2013). World Development Indicators. The World Bank. https://doi.org/10.1596/978-0-8213-9824-1

Willett Kempton, \& Toru Kubo. (2000). Electric-drive vehicles for peak power in Japan. Energy Policy. https://doi.org/10.1016/S0301-4215(99)00078-6

Yeagar, K. (2012). Energy and Economy. In Global Energy Assessment: Toward a Sustainable Future. https://doi.org/10.1017/CBO9780511807756.003

Zhou, W., Lou, C. Z., Li, Z. S., Lu, L., \& Yang, H. X. (2010). Current status of research on optimum sizing of stand-alone hybrid solar-wind power generation systems. Applied Energy. https://doi.org/10.1016/j.apenergy.2009.08.012

\section{Notes}

Note 1. According to the World Climate Change Vulnerability Index, as quoted in the NDC (2016), Nigeria is one of the ten most climate-vulnerable countries, and Lagos is the tenth most vulnerable city in the world (Roche et al., 2017a).

Note 2. Vision 20:2020 Establish generation capacity targets of 35,000 MW in the power sector, it also outlines the path for the global and national vision to position the country among the leading 20 economies of the world in 2020 and aims at a holistic transformation of the economy (Roche et al., 2017a).

Note 3. Vision 30:2030 assumes a target of 30\% share of renewable energy in the energy mix by 2030 , amounting to 30,000 MW of total electricity generation capacity (Roche et al., 2017a). 


\section{Appendix A.}

Table 1. Component costs

\begin{tabular}{|c|c|}
\hline Component & Cost \\
\hline Cost of electricity in Nigeria $[\$ / K W h]$ & $\begin{array}{l}0.06 \text { (Roche et al., 2017b), (NERC, 2016), } \\
\text { (average DISCO MTYOs) }\end{array}$ \\
\hline Cost of grid extension $[\$ / \mathrm{km}]$ & $\begin{array}{l}25,000.00 \text { (Longe et al., 2017), (Electrication, } \\
2000)\end{array}$ \\
\hline Cost of diesel $[\$ / 1]$ & 0.7(Nigeria National Bureau of Statistics, 2017) \\
\hline Cost of Hydro, replacement and O\&M [\$/KW] & $\begin{array}{l}\text { 1,300.00, } 870.00 \text { and } \$ 100 / y r \text {. (World Bank, } \\
\text { 2012), (Roche et al., 2017b) }\end{array}$ \\
\hline Cost of Wind, replacement and O\&M [\$/KW] & $\begin{array}{l}\text { 1,500.00, 1,400.00 and } \$ 0.03 / \text { yr. (Roche et al., } \\
\text { 2017a), (Fitzgerald \& Voege, 2010) }\end{array}$ \\
\hline Cost of PV, replacement and O\&M [\$/KW] & $\begin{array}{l}\text { 4,000.00, 3,500.00 and } 0.00 \text { (Sector, } \\
\text { 2016),(Willett Kempton \& Toru Kubo, 2000) }\end{array}$ \\
\hline Cost of battery, replacement and O\&M [\$/KWh] & $\begin{array}{l}\text { 300.00, } 300.00 \text { and \$10.00/yr. (Lau, Yousof, } \\
\text { Arshad, Anwari, \& Yatim, 2010) }\end{array}$ \\
\hline Cost of converter, replacement and O\&M [\$/KW] & $\begin{array}{l}900.00,700.00 \text { and } 0.00 \text { (Willett Kempton \& } \\
\text { Toru Kubo, 2000) }\end{array}$ \\
\hline Interest rate Nigeria & $5.75 \%$ (World Bank, 2013) \\
\hline Inflation rate Nigeria & $16.5 \%$ (Ley et al., 2014) \\
\hline
\end{tabular}

\section{Copyrights}

Copyright for this article is retained by the author(s), with first publication rights granted to the journal.

This is an open-access article distributed under the terms and conditions of the Creative Commons Attribution license (http://creativecommons.org/licenses/by/4.0/). 